\title{
SITE FIDELITY AND MOVEMENT PATTERNS OF REEF MANTA RAYS (MOBULA ALFREDI: MOBULIDAE) USING PASSIVE ACOUSTIC TELEMETRY IN NORTHERN RAJA AMPAT, INDONESIA
}

\author{
Edy Setyawan 1,2,3,",Abraham B. Sianipar ${ }^{4}$, Mark V. Erdmann ${ }^{5}$, Andrew M. Fischer ${ }^{1}$, \\ James A. Haddy ${ }^{1}$, Calvin S. Beale ${ }^{6}$, Sarah A. Lewis ${ }^{2,3,6}$, Ronald Mambrasar ${ }^{4}$ \\ ${ }^{1}$ Institute for Marine and Antarctic Studies, University of Tasmania, Australia \\ ${ }^{2}$ Sea Sanctuaries Trust, United Kingdom \\ ${ }^{3}$ Manta Trust - Indonesian Manta Project, Indonesia \\ ${ }^{4}$ Conservation International Indonesia - Marine Program, Indonesia \\ ${ }^{5}$ Conservation International - Asia Pacific Marine Programs, New Zealand \\ ${ }^{6}$ Misool Manta Project, Indonesia \\ *e-mail: edysetyawan@gmail.com
}

Received: 10.03.2018

\begin{abstract}
Though extremely valuable to the local marine tourism industry, there is a dearth of published information on the ecology and population dynamics of reef manta rays (Mobula alfredi) in Raja Ampat, West Papua, Indonesia. Knowledge of the movement ecology in particular of this large and scattered population is urgently needed to better manage the rapidly expanding manta-focused tourism. Here we report the results of an initial passive acoustic telemetry study designed to provide local managers with the first detailed knowledge of the site use and movement patterns of reef mantas in northern Raja Ampat. A total of 39 reef mantas were tagged with Vemco V16 acoustic transmitters over a 15-month period between 27 November 2013 and 22 February 2015. To monitor their movements, VR2W acoustic receivers were deployed at eight sites corresponding to known manta cleaning and feeding aggregation sites, with receivers downloaded every six months over a two-year initial monitoring period. The duration between tag deployments and last date of detections at sites ranged from 1 to 682 days (mean $\pm \mathrm{SE}=237 \pm 27$ ). The cumulative number of days of manta detections at receiver sites by individual mantas ranged from 1 to 188 days (mean $\pm \mathrm{SE}=42 \pm 7$ ). Manta Ridge was the most visited site with 565 days of detections. The tagged mantas demonstrated strong site fidelity to the observed aggregation sites. At the same time, they also exhibited seasonal movements within an approximately $150 \mathrm{~km}$ long corridor between sites in the Dampier Strait and the northwest of Waigeo Island. Data analysed from a nearby array of six VR2W receivers in southern Raja Ampat (approximately $180 \mathrm{~km}$ to the south of the study area) confirmed that none of the tagged mantas were detected in this array, providing further evidence of strong site fidelity and limited movements within northern Raja Ampat. More than 96\% of detections occurred during the daytime. The number of detections reached a peak around noon at Yefnabi Kecil and Eagle Rock and slightly earlier at Manta Ridge. These findings have been shared with the Raja Ampat Marine Protected Area Management Authority and are now being used in the formulation of a management plan for this vulnerable and economically important species to ensure the long-term health of Raja Ampat's reef mantas and the sustainability of manta tourism in the region.
\end{abstract}

Key words: management, Marine Protected Area, reef manta, seasonal movement, tagging, West Papua

\section{Introduction}

Long considered a junior synonym of the oceanic manta ray Mobula birostris (Walbaum, 1792), the reef manta ray Mobula alfredi (Krefft, 1868) was shown by Marshall et al. (2009) to represent a valid species based upon consistent morphological, meristic, colour pattern and behavioural differences. Since the publication of this crucial finding, a wide range of studies from across the Indo-Pacific region, from the Marquesas to the Red Sea, have dramatically increased our knowledge of the ecology and behaviour of reef manta rays using a combination of photo identification database development (and associated mark-recapture methodologies), acoustic and satellite telemetry, and stable isotope and population genetic analyses (Dewar et al., 2008; Clark, 2010; Marshall \& Bennett, 2010; Anderson et al., 2011; Couturier et al., 2011, 2012, 2013, 2014; Deakos et al., 2011; Marshall et al., 2011; Jaine et al., 2012; 2014; Kashiwagi et al., 2012; Kitchen-Wheeler et al., 2012; Mourier, 2012; Braun et al., 2014, 2015; Germanov \& Marshall, 2014; Weeks et al., 2015).

The $45000 \mathrm{~km}^{2}$ Raja Ampat Archipelago in West Papua, Indonesia (Fig. 1) is home to a large 
population of reef manta rays (Mangubhai et al., 2012) and is one of only a handful of sites worldwide where both species of manta ray are regularly encountered (Kashiwagi, 2014), including at a number of cleaning stations utilised by both species simultaneously (Authors' data). Raja Ampat's manta rays are considered an extremely important economic asset, bringing in an estimated US\$2.6 million annually in direct expenditures for manta watching tourism in this remote regency (O'Malley et al., 2013). Due in large part to the high value of mantas for marine tourism, the Raja Ampat government in 2012 designated the entire archipelago as Southeast Asia's first shark and ray sanctuary (Fox, 2013), which in turn spurred the Indonesian government to grant both species of manta ray full protected species status nationally in 2014 through Ministerial Decree of Marine Affairs and Fisheries No. 4/2014 (Erdmann, 2014; Ministry of Marine Affairs and Fisheries, 2014).

Despite the high economic value of Raja Ampat's manta rays, there are very little published data on their spatial ecology and population dynamics. Mangubhai et al. (2012) report known aggregations of $M$. alfredi from four of Raja Ampat's eight marine protected areas (MPAs), while Stewart et al. (2016) describe the movements of ten $M$. birostris individuals as revealed by satellite tagging. This relative dearth of information impedes effective manta conservation in the region, as understanding the movement patterns and habitat preferences of potentially migratory elasmobranch species is widely considered critical for determining effective management strategies (Graham et al., 2012).

In order to address this situation, a manta ray conservation research programme was launched in 2011 as a partnership between the Manta Trust, Indonesia Manta Project, Misool Manta Project and Conservation International to provide the Raja Ampat government with the critical data needed to effectively protect Raja Ampat's oceanic and reef manta rays and design appropriate manta ray tourism management regulations (Heinrichs, 2013). To address these needs, this research program employs the use of photo identification and satellite and acoustic telemetry techniques, with this paper outlining our initial acoustic telemetry study to elucidate movement patterns of $M$. alfredi in northern Raja Ampat.

The use of passive acoustic telemetry for movement monitoring provides several substantial benefits. Firstly, passive acoustic telemetry can be used extensively to track a wide range of species and multiple individuals concurrently and their habitat uses in different habitats (Delaney et al., 2012; Heupel \& Webber, 2012; Donaldson et al., 2014). Secondly, acoustic telemetry can operate continuously and provide high temporal and spatial (depending on receiver location) resolution data (Kessel et al., 2014). In a number of recent studies, passive acoustic telemetry has been used successfully in examining movement patterns, site fidelity and seasonal occurrences of reef manta rays at monitored sites (Couturier et al., 2012). In the Red Sea, acoustically-tagged reef mantas demonstrate frequent movements between reefs, with short residency periods (Braun et al., 2015). Similarly, acoustic tagging was used in Komodo (Indonesia) to show that reef mantas exhibit high fidelity and seasonal movements between known aggregation sites (Dewar et al., 2008).

In this study, we deployed an array of passive acoustic receivers (Heupel et al., 2006) at wellknown reef manta feeding and cleaning aggregation sites in northern Raja Ampat and deployed acoustic transmitters on $M$. alfredi in order to: 1) investigate movement patterns of reef mantas in northern Raja Ampat; 2) determine the degree to which reef mantas in Raja Ampat exhibit site fidelity; and 3) elucidate any clear seasonal or diurnal patterns in manta ray detections at the eight aggregation areas.

\section{Material and Methods}

\section{Tag deployments}

The tagging was carried out with the approval of the Raja Ampat MPA Management Authority. A total of 39 individuals of reef manta rays $M$. alfred $i$ were tagged using acoustic transmitters (model V16-6H, Vemco Inc., Nova Scotia, Canada) that were coated with non-toxic Propspeed ${ }^{\mathrm{TM}}$ (OceanMax, Auckland, New Zealand) silicone coating to prevent fouling of tags during deployment. Each transmitter emitted a uniquely coded acoustic signal at random intervals between 60 and $120 \mathrm{sec}-$ onds. The V16 tags were attached to a titanium dart with a $12-\mathrm{cm}$ long stainless steel tether, and were deployed externally on reef manta rays using a pole spear to insert the titanium dart into the dorsum of the ray in the crease between the left wing and the body cavity. Darts were inserted to a depth of $5 \mathrm{~cm}$ into the musculature of the ray, effectively anchoring the tethered tag near the trailing edge of the left wing. Prior to tagging, ventral photographs of each individual were taken to ensure no individual was tagged more than once (Marshall et al., 2011), and the sex was recorded. 


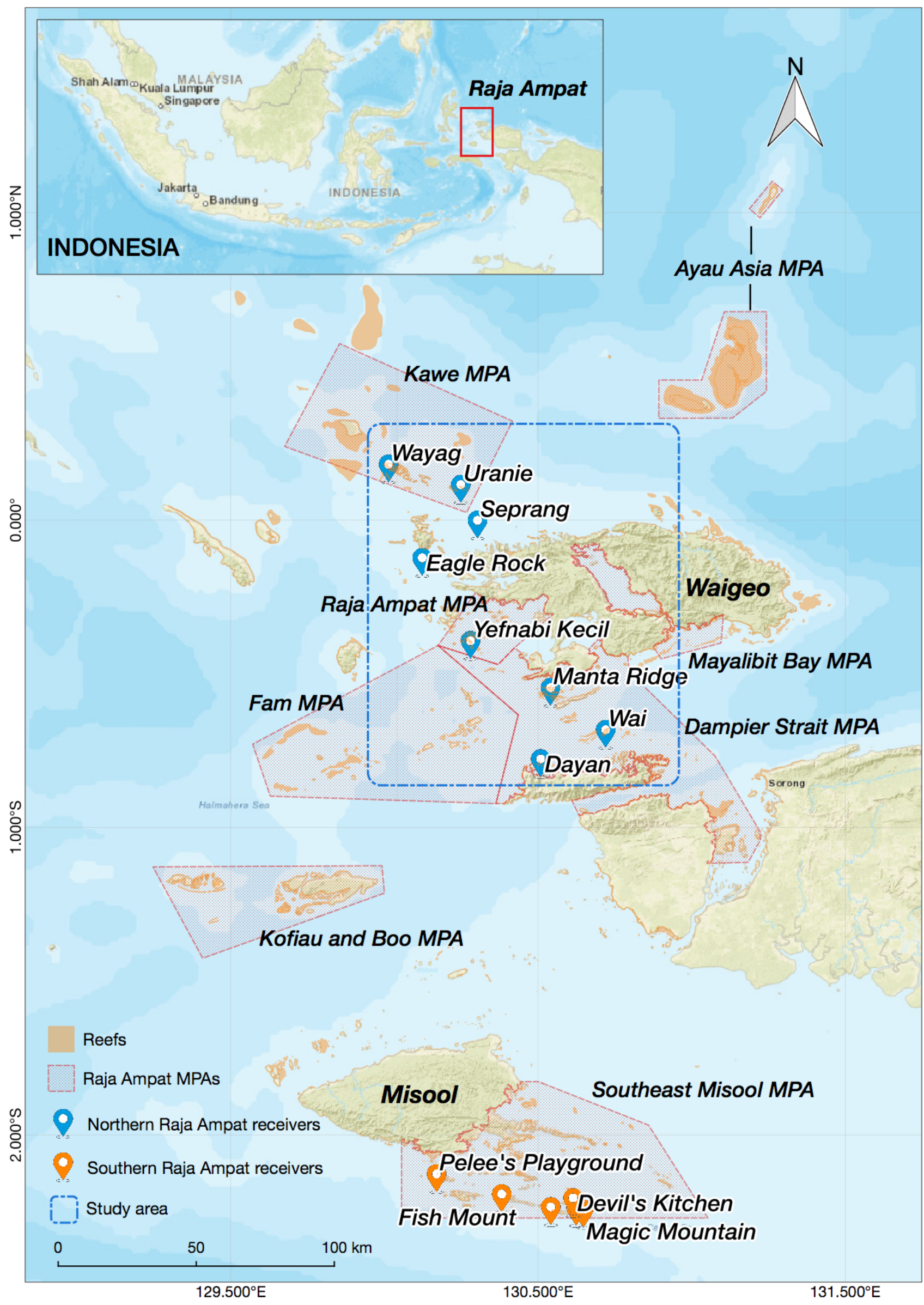

Fig. 1. Raja Ampat Marine Protected Area Network (Indonesia) and the location of the VR2W acoustic arrays. The acoustic array in Southeast Misool was installed independently; however, we had access to data from this array to check for any visits by mantas tagged in our study. 


\section{Acoustic array}

The acoustic array consisted of eight VR2W-69 $\mathrm{kHz}$ acoustic monitoring receivers (Vemco Inc., Nova Scotia, Canada). It was sited along an approximately $150 \mathrm{~km}$ long corridor in northern Raja Ampat where mantas are most frequently observed, with each site corresponding to a known reef manta cleaning and/or feeding aggregation site. The sites were located in Wayag, Uranie, Seprang, Yefnabi Kecil, Eagle Rock, Manta Ridge, Dayan, and Wai islands (Fig. 1). A receiver was deployed at each site at depths ranging from 8.5 to $35.0 \mathrm{~m}$. The receivers were securely cable-tied to buoyed moorings that were directly attached to the substrate using galvanised chain anchors, with each receiver approximately $2 \mathrm{~m}$ above the surrounding substrate. They were used to record all acoustic pings emitted by acoustic transmitters on tagged mantas passing within the receiver's detection range. Acoustic data, which were retrieved from the receivers every six months, consisted of the date-time stamps of detections and transmitter/tag IDs. During each retrieval, we made sure that PC clock and the internal clock of the receiver were the same in order to avoid significant shifts in the time records of the detected tags.

\section{Range test}

A range test was conducted at Yefnabi Kecil. A tag was placed in the water on the side of the boat while drifting with the tidal current. A handheld Global Positioning System (GPS) was used to document the exact time and location of the boat. These were then matched with the date-time stamp of detections recorded by the receiver in Yefnabi Kecil. The distance between the receiver and the location of approximate last detection recorded by the receiver was measured. Our range test showed reliable detection when the tag was within approximately $120-150 \mathrm{~m}$ of the receiver. This is similar to detection in the Seychelles Amirantes acoustic array (Lea, 2017).

\section{Data analysis}

All acoustic data were filtered out for any pings that were recorded before the tags were deployed on reef manta rays and did not correspond to both active tags and receivers. Acoustic data then were analysed to characterise the detection and movement patterns of reef manta rays to and between sites. Detection patterns were investigated by examining the date-time stamps of detections recorded by receivers. A detection event is defined as a period of time, during which a tagged manta was detected continuously by a receiver. It begins when a transmitter is detected by a given receiver, and terminates if either the transmitter is not detected again by that receiver within an hour, or if the transmitter is detected by another receiver (Campbell et al., 2012). The duration of each detection event and the interval between detections recorded by other receivers were calculated (Dewar et al., 2008). The monthly cumulative number of days of individual mantas recorded by each receiver was also calculated to investigate the preferred time of year of manta detection to each receiver site.

\section{Statistical analysis}

Generalised additive models (GAMs) were used to elucidate the relationship between manta detection (response) and temporal predictors. GAMs can be used with non-parametric data (Hastie et al., 2005) to cope with variable and highly non-linear relationships between responses and a number of predictors (Guisan et al., 2002). A GAM was implemented for each aggregation site that was most-frequently visited by reef manta rays. The response used in each model was the daily cumulative number of detections, whereas the temporal predictors were hour of day (diel pattern) and day of year (season). In this study, the GAM was performed in RStudio using the 'mgcv' package (Wood \& Wood, 2007). REML was used for smoothness selection to fit the model to the data (Wood, 2011).

\section{Reef manta tagging}

A total of 39 mantas were tagged in three different periods, consisting of 14 mantas between November and December 2013, 13 mantas between April and May 2014, and 12 mantas in February 2015. The mantas were tagged in various locations near the receivers, with the majority (28 individuals) tagged at cleaning stations and feeding aggregation sites near Manta Ridge (Table 1). The remaining mantas were tagged at Eagle Rock (eight mantas), Yefnabi Kecil (two mantas), and the lagoon of Wayag (one manta). Overall, the tagged mantas consisted of 30 females, 7 males, and 2 individuals for which sex was not determined. 
Table 1. Summary of the tagging and detection activities of 39 reef manta rays (Mobula alfredi) tagged in northern Raja Ampat between November 2013 and February 2015

\begin{tabular}{|c|c|c|c|c|c|c|c|c|}
\hline $\begin{array}{c}\text { Manta } \\
\#\end{array}$ & Sex & Tagging location & Tagging date & $\begin{array}{c}\text { Tagging duration } \\
\text { (days) }\end{array}$ & $\begin{array}{l}\text { \# Days of } \\
\text { detections }\end{array}$ & $\begin{array}{l}\text { \# Receivers } \\
\text { visited }\end{array}$ & \# Movements & $\begin{array}{c}\text { \# Redetection } \\
\text { events }\end{array}$ \\
\hline 1 & $\mathrm{~F}$ & Wayag & 25 Nov 2013 & 98 & 6 & 3 & 3 & 2 \\
\hline 2 & $\mathrm{U}$ & Eagle Rock & 27 Nov 2013 & 364 & 44 & 2 & 2 & 63 \\
\hline 3 & $\mathrm{~F}$ & Eagle Rock & 27 Nov 2013 & 435 & 94 & 3 & 10 & 160 \\
\hline 4 & M & Eagle Rock & 27 Nov 2013 & 112 & 14 & 2 & 4 & 20 \\
\hline 5 & $\mathrm{~F}$ & Yefnabi Kecil & 27 Nov 2013 & 113 & 23 & 3 & 2 & 39 \\
\hline 6 & M & Yefnabi Kecil & 28 Nov 2013 & 34 & 24 & 1 & - & 51 \\
\hline 7 & $\mathrm{~F}^{*}$ & Manta Ridge & 29 Nov 2013 & 682 & 188 & 4 & 28 & 237 \\
\hline 8 & $\mathrm{~F}$ & Manta Ridge & 29 Nov 2013 & 163 & 52 & 4 & 18 & 61 \\
\hline 9 & $\mathrm{~F}$ & Manta Ridge & 30 Nov 2013 & 455 & 54 & 3 & 19 & 45 \\
\hline 10 & $\mathrm{~F}$ & Manta Ridge & 30 Nov 2013 & 40 & 14 & 1 & - & 15 \\
\hline 11 & $\mathrm{~F}$ & Manta Ridge & 1 Dec 2013 & 184 & 40 & 2 & 3 & 57 \\
\hline 12 & $\mathrm{~F}$ & Manta Ridge & 1 Dec 2013 & 562 & 171 & 4 & 39 & 196 \\
\hline 13 & $\mathrm{~F}$ & Manta Ridge & 28 Nov 2013 & 670 & 60 & 5 & 22 & 49 \\
\hline 14 & $\mathrm{~F}$ & Manta Ridge & 1 Dec 2013 & 356 & 54 & 3 & 11 & 66 \\
\hline 15 & $\mathrm{~F}$ & Manta Ridge & 24 Apr 2014 & 76 & 1 & 1 & - & - \\
\hline 16 & M & Manta Ridge & 25 Apr 2014 & 357 & 34 & 5 & 18 & 22 \\
\hline 17 & $\mathrm{~F}$ & Manta Ridge & 25 Apr 2014 & 129 & 19 & 3 & 6 & 14 \\
\hline 18 & $\mathrm{~F}$ & Manta Ridge & 26 Apr 2014 & 169 & 4 & 1 & - & 3 \\
\hline 19 & $\mathrm{~F}$ & Manta Ridge & 26 Apr 2014 & 294 & 97 & 4 & 16 & 114 \\
\hline 20 & $\mathrm{~F}$ & Manta Ridge & 26 Apr 2014 & 11 & 1 & 1 & - & 1 \\
\hline 21 & $\mathrm{~F}$ & Manta Ridge & 30 Apr 2014 & 161 & 29 & 3 & 2 & 44 \\
\hline 22 & $\mathrm{~F}$ & Manta Ridge & 3 May 2014 & 1 & 1 & 1 & 0 & - \\
\hline 23 & $\mathrm{~F}$ & Manta Ridge & 3 May 2014 & 275 & 46 & 4 & 5 & 55 \\
\hline 24 & M & Manta Ridge & 3 May 2014 & 135 & 12 & 2 & 1 & 13 \\
\hline 25 & M & Manta Ridge & 3 May 2014 & - & - & - & - & - \\
\hline 26 & $\mathrm{U}$ & Manta Ridge & 3 May 2014 & 5 & 1 & 1 & - & - \\
\hline 27 & $\mathrm{~F}$ & Manta Ridge & 3 Feb 2015 & 273 & 31 & 4 & 10 & 27 \\
\hline 28 & $\mathrm{~F}^{*}$ & Manta Ridge & 3 Feb 2015 & 178 & 35 & 3 & 6 & 35 \\
\hline 29 & M & Manta Ridge & 3 Feb 2015 & 244 & 74 & 4 & 12 & 119 \\
\hline 30 & M & Manta Ridge & $14 \mathrm{Feb} 2015$ & 190 & 110 & 3 & 5 & 237 \\
\hline 31 & $\mathrm{~F}$ & Manta Ridge & $14 \mathrm{Feb} 2015$ & 272 & 63 & 5 & 15 & 100 \\
\hline 32 & $\mathrm{~F}$ & Manta Ridge & 3 Feb 2015 & 267 & 13 & 1 & - & 13 \\
\hline 33 & $\mathrm{~F}$ & Manta Ridge & $14 \mathrm{Feb} 2015$ & 239 & 26 & 4 & 5 & 30 \\
\hline 34 & $\mathrm{~F}$ & Eagle Rock & $21 \mathrm{Feb} 2015$ & 268 & 46 & 3 & 4 & 68 \\
\hline 35 & $\mathrm{~F}$ & Eagle Rock & $22 \mathrm{Feb} 2015$ & 260 & 51 & 2 & 2 & 99 \\
\hline 36 & $\mathrm{~F}$ & Manta Ridge & 4 Feb 2015 & 182 & 26 & 4 & 9 & 20 \\
\hline 37 & $\mathrm{~F}^{*}$ & Eagle Rock & $23 \mathrm{Feb} 2015$ & 267 & 25 & 3 & 10 & 33 \\
\hline 38 & $\mathrm{~F}^{*}$ & Eagle Rock & 22 Feb 2015 & 248 & 16 & 3 & 3 & 18 \\
\hline 39 & $\mathrm{~F}$ & Eagle Rock & 22 Feb 2015 & 231 & 6 & 1 & - & 5 \\
\hline
\end{tabular}

Note: $\mathrm{F}$ - females, $\mathrm{M}$ - males, and $\mathrm{U}$ - unknown sex; $\mathrm{F}^{*}$ - pregnant females.

\section{Visitation to receivers}

The acoustic monitoring of reef manta rays was conducted for a two-year period between 27 November 2013 and 17 November 2015. The acoustic receivers detected a range of manta site fidelity and movements (Table 2). Four receivers (Manta Ridge, Eagle Rock, Yefnabi Kecil, and Wai) recorded the highest level of detec- tions among all receivers. Manta Ridge was the most visited site, with a total of 24 tagged mantas detected by the receiver at this site. This was followed by Eagle Rock $(\mathrm{n}=22)$, Yefnabi Kecil $(n=22)$, and Wai $(n=19)$. By contrast, receivers in Wayag, Uranie, Dayan, and Seprang recorded fewer than 10 individual mantas during the study period. 
Table 2. Summary of receiver deployment and detections recorded by eight VR2W acoustic receivers deployed in northern Raja Ampat between November 2013 and November 2015

\begin{tabular}{lccccccc}
\hline \multicolumn{1}{c}{ Sites } & $\begin{array}{c}\text { Receiver } \\
\text { deployment } \\
\text { date }\end{array}$ & Primary site use & $\begin{array}{c}\text { Total \# } \\
\text { detected } \\
\text { mantas }\end{array}$ & $\begin{array}{c}\text { Cumulative } \\
\text { \# days of } \\
\text { detection }\end{array}$ & $\begin{array}{c}\text { Cumulative } \\
\text { \# detection } \\
\text { events }\end{array}$ & $\begin{array}{c}\text { Average duration } \\
\text { of detection event } \\
\text { (mins) }\end{array}$ & $\begin{array}{c}\text { Cumulative } \\
\text { \# redetection } \\
\text { events }\end{array}$ \\
\hline Wayag & $25 / 11 / 2013$ & Feeding & 6 & 70 & 112 & 13.5 & 100 \\
Uranie & $26 / 11 / 2013$ & Cruising & 7 & 19 & 29 & 23.1 & 20 \\
Seprang & $26 / 11 / 2013$ & Cruising & 1 & 1 & 1 & 1.8 & 0 \\
Eagle Rock & $27 / 11 / 2013$ & Cleaning \& Feeding & 22 & 287 & 479 & 73.4 & 434 \\
Yefnabi Kecil & $27 / 11 / 2013$ & Cleaning \& Feeding & 22 & 434 & 821 & 75.0 & 757 \\
Manta Ridge & $28 / 11 / 2013$ & Cleaning \& Feeding & 24 & 565 & 699 & 30.9 & 584 \\
Wai & $28 / 11 / 2013$ & Cleaning \& Feeding & 19 & 202 & 278 & 7.8 & 212 \\
Dayan & $28 / 11 / 2013$ & Cleaning \& Feeding & 5 & 27 & 40 & 13.6 & 24 \\
\hline
\end{tabular}

The percentage of monitoring days for each receiver, recording at least one detection, varied significantly, with an average of $27.9 \%$ of the monitoring period across all eight receivers. The Manta Ridge receiver recorded detections on $78.5 \%$ of the days during the monitoring period ( 565 out of 720 days), followed by Yefnabi Kecil (60.3\%), Eagle Rock (39.9\%), and Wai (28.1\%). Based on the cumulative number of days of detection, the number of detection events, and the number of redetection events, approximately $93 \%$ of manta detections occurred at these four sites. Yefnabi Kecil had the highest cumulative number of detection events and the longest average duration of detection events with 821 detection events and 75 mins of average duration of detection event respectively. The number of redetection events in Yefnabi Kecil was the highest of all sites. Redetection events occurred when a detection event of a manta was terminated (after one hour of non-detection) and the manta was subsequently recorded again by the same receiver, before being detected by other receivers.

\section{Manta movements}

The detection and movement patterns of individual tagged mantas are summarised in Table 1 and Fig. 2. Of the 39 tagged mantas, 38 were recorded by our acoustic receivers. One tag on manta \#25 was not detected after tagging, indicating that the tag may have detached shortly after tagging or that the manta left the study area. The tagging duration, calculated as the number of days from initial deployment until the last date of detection at the receivers, ranged from 1 to 682 days (mean $\pm \mathrm{SE}=237 \pm 27$ ). The cumulative numbers of days of detections by each individual manta varied between 1 and 188 days (mean $\pm \mathrm{SE}=$ $42 \pm 7$ ). In most cases, mantas spent on average 45 \pm 5.2 mins at one site (Fig. 2). The longest detection event was 14.3 hours, recorded by manta $\# 30$ on 9 July 2015 in Yefnabi Kecil.

The movement and site preferences of mantas were examined from their site detection patterns. An examination of consecutive detection events reveals that individual mantas in Raja Ampat appear to prefer revisiting the same site as opposed to aggregating across multiple sites (Fig. 2). Of all detection events recorded by the 39 tagged mantas, nearly $87 \%$ of these events showed re-visitation to the same site (Table 1). Overall, the number of redetections per manta had a mean $( \pm$ SE) of $61 \pm 11$ events, while the average number of movement (i.e., between receivers) per manta was $10 \pm 2$ events. The number of redetection and movement events to other receiver sites varied among individual mantas. For example, during a 682-day tagging duration, manta \#7 was detected by four receivers: Eagle Rock, Yefnabi Kecil, Manta Ridge, and Wai with 28 movement events (Fig. 2). It was redetected by three receivers with a total of 237 redetection events, of which nearly $70 \%$ of the redetection events occurred at Manta Ridge and the rest were at Yefnabi Kecil and Wai. By comparison, manta \#12, which had 196 redetection events ( $60 \%$ of which also occurred at Manta Ridge), possessed the most movement events (39) of all other individuals.

Most mantas were detected by more than one receiver during the study period. Almost one third of the tagged mantas were detected by three receivers, and nearly a quarter of the tagged mantas were detected by four receivers (Table 1). Unsurprisingly, the most common movement patterns were between the four most heavily visited sites (which form an approximately $100 \mathrm{~km}$ long corridor from southern Dampier Strait to northwest Waigeo Island), accounting for nearly $78 \%$ of all movement events. Within the Dampier Strait, more than 40\% of all movement events occurred among three sites 
that were approximately $25-30 \mathrm{~km}$ apart. At the site level, the most frequent movement was from Manta Ridge to Wai with 50 events (17\% of all recorded movement events for all mantas), followed by movement from Wai to Manta Ridge with 44 events (15\%). Moreover, Yefnabi Kecil in the west of Waigeo Island seems highly connected with sites in the Dampier Strait. A total of 40 movement events (14\%) were made from Manta Ridge to Yefnabi Kecil. In the opposite direction, 37 events (13\%) occurred from Yefnabi Kecil to Manta Ridge.

\section{Site preference}

To investigate site preference in more detail, seven individual mantas tagged in the vicinity of Manta Ridge ( $\mathrm{n}=5$, mantas \#7, 9, 12, 13, and 14) and at Eagle Rock $(n=2$, mantas \#2 and 3$)$ had their detection pattern to sites examined. These mantas were specifically chosen as being those with more than 350 days of tagging duration and having registered at least 65 detection events during the study period, which is more than the average number of detection events by all individuals. Mantas tagged at Eagle Rock were detected most frequently on the Eagle Rock receiver (98.5\% and 95.3\%) (Fig.
3). By comparison, $56 \%$ of manta detection in the vicinity of Manta Ridge were recorded by the receiver closest to where they were tagged. Several of these mantas were detected by receivers at Yefnabi Kecil and Wai, which are located approximately $34 \mathrm{~km}$ and $28 \mathrm{~km}$ apart from Manta Ridge, respectively. It is likely that there is a division between sites in northwest Waigeo (including Eagle Rock) and sites around Dampier Strait (including Yefnabi Kecil) in terms of manta movements.

\section{Seasonal movements}

The monthly cumulative number of days of detections at each site was used to examine the pattern of manta detections to a given site during the study period (Fig. 4). As noted previously, the majority of manta detections occurred at the four sites of Eagle Rock, Yefnabi Kecil, Manta Ridge, and Wai. By contrast, the other sites (Wayag, Uranie, Seprang, and Dayan) experienced a smaller number of days of detections (Fig. 4). Generalised additive models (GAMs) revealed that day of year was a significant predictor for the daily cumulative number of detections at the four main sites. GAMs show significant seasonal differences between sites.

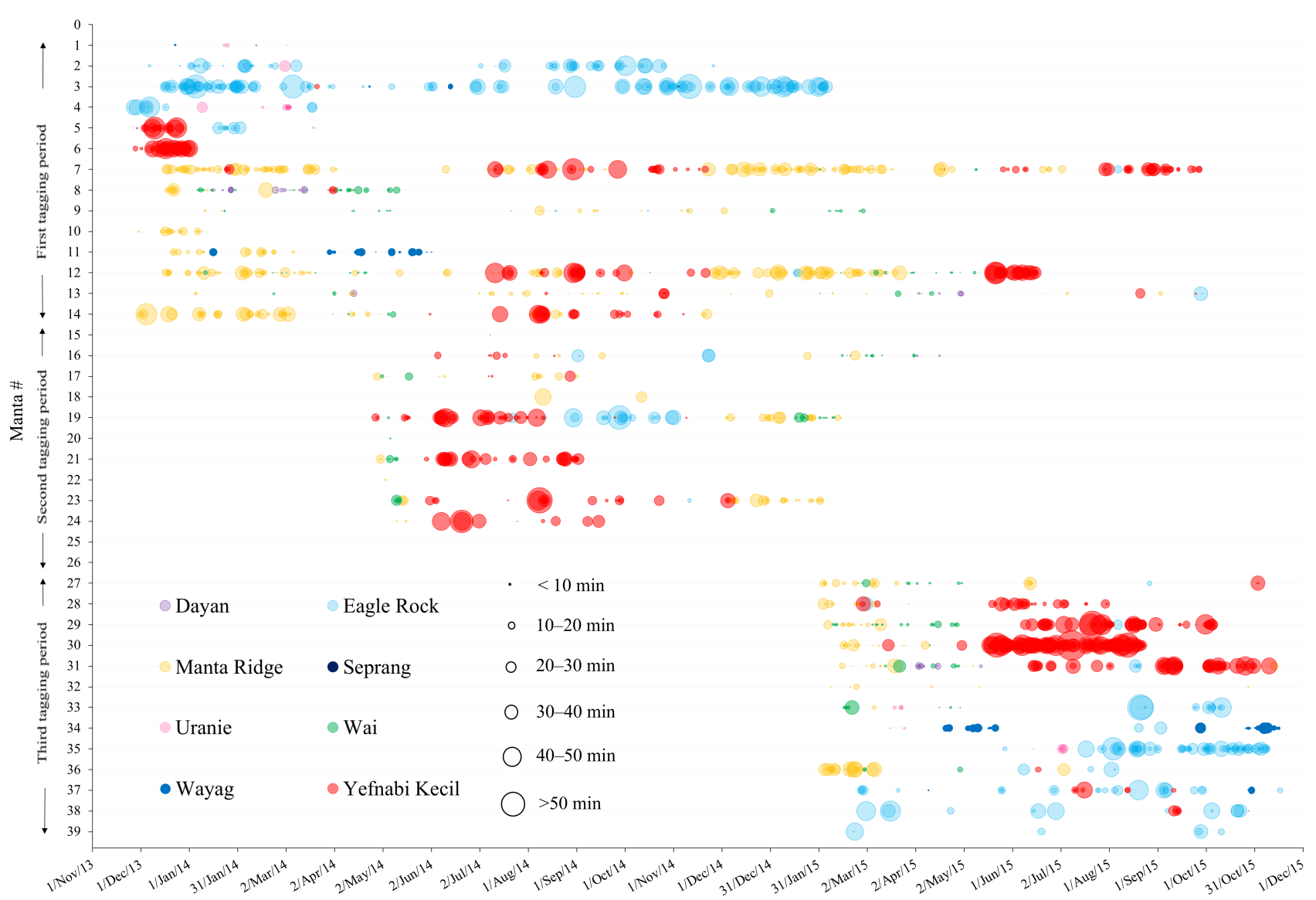

Fig. 2. The detection patterns of thirty nine tagged reef manta rays (Mobula alfredi) $(\mathrm{n}=39)$ recorded by receivers $(\mathrm{n}=8)$ in northern Raja Ampat between November 2013 and November 2015. The size of the bubbles represents the duration of each detection event at a given site by a manta. 


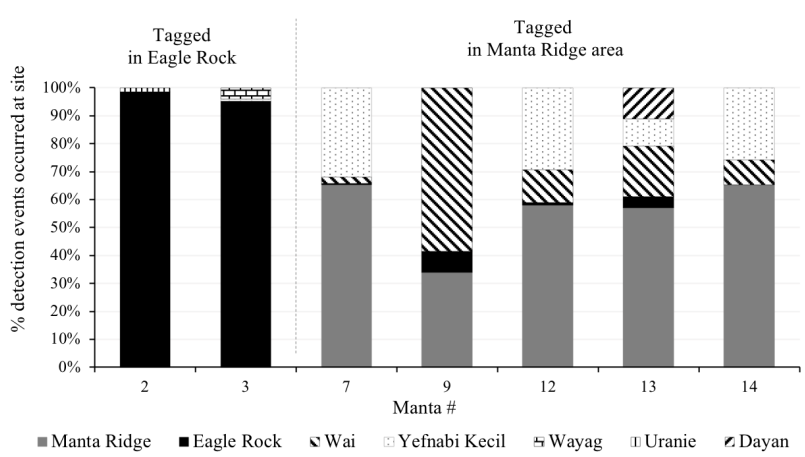

Fig. 3. Percentage of detection events recorded at each receiver site $(\mathrm{n}=8)$ by the seven tagged reef manta rays (Mobula alfredi) with a detection span of more than 350 days and with at least 65 detection events each.

At both Eagle Rock and Yefnabi Kecil, tagged mantas were detected nearly throughout the year (Fig. 4). At Eagle Rock, manta detection peaked in January and October, with the highest monthly cumulative number of days of detections occurring in January 2014 and October 2015 (31 days for each of these months). It was notably lower in April and May than during other months of the year, which was also confirmed by the GAM $(p<0.01)$. By contrast, the manta peak season in Yefnabi Kecil was between June and August, with the lowest number of detections occurring in February $(\mathrm{p}<0.01)$. In June 2015, the cumulative number of days of detections to Yefnabi Kecil reached up to 70 days by seven mantas.
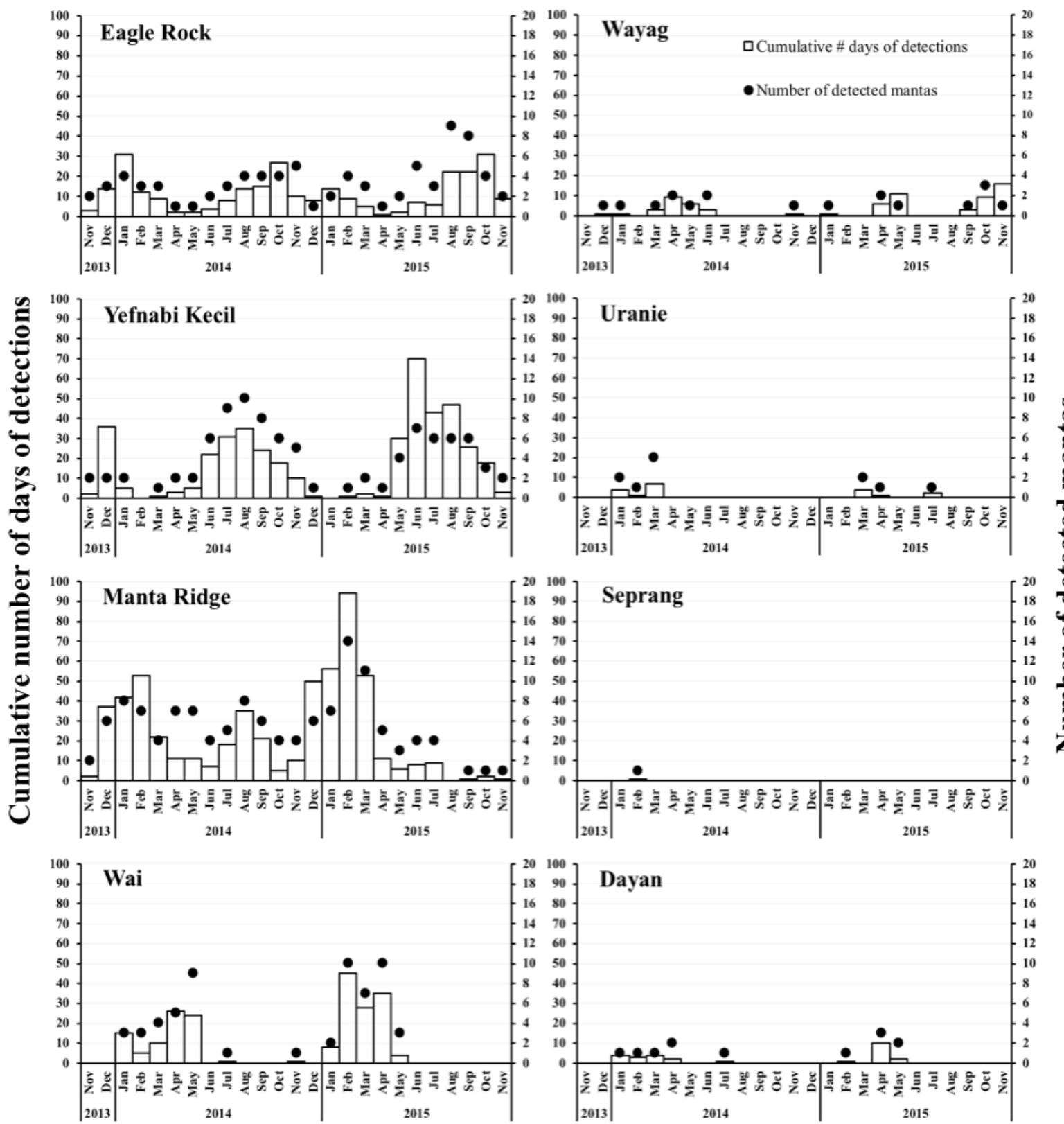

Months of Years

Fig. 4. Monthly cumulative number of days of detections (bars) and total number of reef manta rays (Mobula alfredi) detected at each site during a given month (filled circles) between November 2013 and November 2015 in northern Raja Ampat. 
In Manta Ridge, mantas were detected throughout most of the year, peaking from December to February as also revealed by GAM ( $p<0.01)$. In 2014, a secondary peak was observed in August, but this was not recorded in 2015. Manta detections in Wai were relatively sparse, ranging from 1 to 45 days of detections per month. Mantas were mostly detected between January and May $(\mathrm{p}<0.01)$ in both 2014 and 2015. In contrast to the aforementioned sites, receivers at Wayag, Uranie, Seprang, and Dayan recorded detections sporadically, with a maximum of 15 days of detections in a given month throughout the study period, and usually fewer (Fig. 4).

An examination of the data recorded by the six acoustic receiver array owned by Misool Eco Resort in southern Raja Ampat showed that none of our tagged mantas were detected by this array during the entire duration of our study (Beale, unpublished data).

\section{Diel pattern}

The distribution of acoustic detections by hour of day is shown in Fig. 5 for the four most frequentlyvisited sites in our study. Approximately $96 \%$ of all detections were recorded during the daytime. Overall, the number of detections gradually increased starting at $6.00 \mathrm{a} . \mathrm{m}$. and reached a peak around noon, before progressively declining by 7.00 p.m. GAMs revealed that hour of day was a significant predictor for daily cumulative number of detections. Activity at Manta Ridge peaked slightly earlier (between 10.00 a.m. and 11.00 a.m. $)(p<0.01)$ than at Yefnabi Kecil and Eagle Rock, at which manta visitation peaked around noon $(p<0.01)$. On the other hand, there was no clear pattern of manta visitation at Wai $(\mathrm{p}>0.01)$. The proportion of detections recorded at night (from 6.00 p.m. to 6.00 a.m.) varied across the four sites, with Wai showing the highest percentage of night-time detections (19.3\%), compared to Yefnabi Kecil (9.0\%), Manta Ridge (2.9\%), and Eagle Rock (1.2\%).

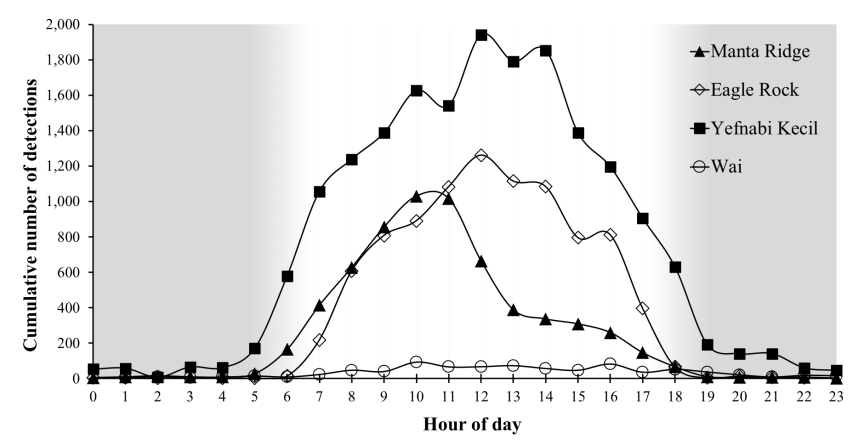

Fig. 5. Cumulative number of detections by hour of day at Eagle Rock, Yefnabi Kecil, Manta Ridge, and Wai between November 2013 and November 2015. The grey shaded areas represent night-time.

\section{Discussion}

\section{Aggregation sites and site fidelity}

This study has confirmed the preference among selected aggregation sites for 39 tagged reef manta rays in northern Raja Ampat. Manta Ridge, Yefnabi Kecil, Eagle Rock, and Wai (Fig. 1) were the most important aggregation sites based on detection events. The tagged mantas also demonstrated significant site fidelity, primarily to those four aggregation sites. As noted in Table 2, all four of these receivers are located in close proximity to both known manta cleaning stations as well as areas of active feeding aggregations.

The site fidelity of reef mantas in northern Raja Ampat is likely associated with their cleaning and feeding activities. For example, the most highly-visited site of Manta Ridge is well-known to host a number of cleaning stations in the immediate vicinity - including several at Manta Ridge and at the nearby dive site of Manta Sandy. Additionally, there are a number of feeding areas in the vicinity of Manta Ridge, such as Mambarayup, where mantas are commonly encountered while surface feeding. With the proximity of feeding and cleaning sites, Manta Ridge and its surroundings are popular for manta diving and snorkelling tourism. Eagle Rock and Wai are also often visited by tourists, and in the past year a number of dive live-aboard vessels have started visiting Yefnabi Kecil as well. However, manta-based tourism activity on these sites is far less intensive than the vicinity of Manta Ridge as a result of the ease of access and manta encounters on the latter site.

Manta site fidelity has also been reported in other locations. Reef mantas in eastern Australia displayed high site fidelity associated with feeding and cleaning activities based on photographic identification (Couturier et al., 2011, 2014) and satellite tracking (Jaine et al., 2014). Photographic identification also revealed the high site fidelity to coastal areas of this species in Hawaii with $75 \%$ of individuals re-sighted multiple times year-round (Clark, 2010). Reef mantas in Mozambique and the Maldives are also frequently re-sighted at known aggregation sites (Marshall et al., 2011; Stevens, 2016). Acoustic telemetry in Komodo National Park (Indonesia) also revealed considerable site fidelity of reef mantas for up to three months of nearly daily visits and up to two years of occasional visits. Moreover, the majority of the tagged mantas demonstrated a tendency to return to locations where they were tagged (Dewar et al., 2008).

In a number of cleaning stations in Raja Ampat, there were more sightings of female $M$. alfredi than males (Setyawan, unpublished data). The fact that at least $77 \%$ of the tagged mantas were females might 
have a significant effect on the level of manta site fidelity recorded by our study. Female elasmobranchs, including reef mantas, are known to demonstrate higher site fidelity than males (Heupel et al., 2010; Marshall et al., 2011; Whitney et al., 2012). In the Maldives, female $M$. alfredi are almost twice as likely to return to the same sites (either cleaning aggregation sites or feeding ground) as males (Stevens, 2016).

Finally, we note that despite the fact that the Southeast Misool acoustic array is only $150 \mathrm{~km}$ from the southernmost receiver in our array (with contiguous reef habitats stretching that entire distance), none of the northern tagged mantas in our study were detected in this acoustic array. This further highlights the high site fidelity of these mantas and the limit of their habitat range in northern Raja Ampat (Fig. 1). Furthermore, there appears to be another segregation in northern Raja Ampat with the mantas tagged in Eagle Rock rarely being detected by the receivers located in Dampier Strait and vice versa (Fig. 2, Fig. 3).

\section{Seasonal and spatial movements}

Concurrently with their site fidelity, the majority of tagged mantas demonstrated seasonal movements between sites. There were regular movements between sites located around Dampier Strait and sites located in the west of Waigeo Island (Fig. 1), primarily between Eagle Rock, Yefnabi Kecil, Manta Ridge, and Wai. The majority of mantas were detected at sites around Dampier Strait (Manta Ridge and Wai) between December and April, while a majority of detections during the period of June through October were recorded at Eagle Rock and Yefnabi Kecil in the west of Waigeo.

These movement patterns are likely associated with the seasonal monsoons affecting the distribution and biomass of phytoplankton and associated zooplankton (Ware \& Thomson, 2005). In Raja Ampat, the northwest monsoon extends generally from November to April. It is characterised by winds emanating from the northwest generating sporadic strong wind and swell. During this period, sea surface temperatures (SSTs) are generally warmer. In contrast, the southeast monsoon extends from May to October and is characterised by strong and continuous southeast winds (Mangubhai et al., 2012). The south-easterly wind drives upwelling, which transports cooler, nutrient-rich water from a greater depth to the near-surface water upper layer, resulting in a strong biological response in terms of primary productivity in coastal areas (Susanto et al., 2006; Rykaczewski \& Checkley, 2008). We hypothesise that during the southeast monsoon, upwelling and primary productivity may be most enhanced along the west coast of Waigeo, which has closer proximity to deep water than do the manta sites in Dampier Strait and thus may show the greatest increase in biomass of the zooplankton upon which mantas prefer to feed (Couturier et al., 2012, 2013). By contrast, during the warmer northwest monsoon, upwelling in west Waigeo would likely cease, and mantas may rely instead upon consistent strong currents in the Dampier Strait to funnel zooplankton to feeding sites there.

The influence of the seasonal monsoon on manta ray movements has also been observed in other locations. In the Maldives, the presence and distribution of reef mantas was strongly correlated with reversing currents, which is driven by seasonal monsoons (Anderson et al., 2011). In Komodo, the distribution of reef mantas was also highly influenced by the monsoon season, with mantas abundant in north Komodo during the Austral summer and in south Komodo during the Austral winter (Dewar et al., 2008). In Lady Elliot Island (LEI), eastern Australia, mantas moved further southward during winter. In contrast, mantas returned northward during summer (Couturier et al., 2011).

Despite the apparent correlation between manta movements and the seasonal monsoon, further study is required to confirm and explain this correlation. We intend to use remote sensing data to examine the spatial and temporal distribution of chlorophyll a concentration and sea surface temperature throughout the study sites. Additionally, incorporating environmental correlates such as tide, wind direction, wind speed, moon phases and monsoon index into future analyses should help elucidate the potential role of these key parameters affecting the behavioural movements of manta rays (Dewar et al., 2008; Jaine et al., 2012, 2014; Weeks et al., 2015).

The regular movement of mantas between sites in Dampier Strait and Yefnabi Kecil suggests a single well-connected manta populations around Dampier Strait area. Apart from this, less frequent movement of mantas between sites in Dampier Strait and northwest Waigeo might suggest another population segregation in northern Raja Ampat. Furthermore, the fact that none of the tagged mantas were detected in Southeast Misool suggests that there is conceivably a different sub-population in southern Raja Ampat. Despite these, it is expected that individuals are moving between these regions to prevent any genetic segregation considering that only 39 individuals were tagged and they were tagged for less than a year on average. Further studies involving genetic analysis are currently planned to corroborate this (Castro et al., 2007). 


\section{Diel pattern}

In general, the mantas demonstrated a distinct diel behaviour pattern of detections (Fig. 5). Reef manta rays spent the majority of the detection period around receiver sites during the day and were rarely detected by receivers at night. This behaviour is likely related to manta feeding strategy and similar patterns were observed in Komodo (Dewar et al., 2008), Lady Elliot Island (Jaine et al., 2012) and Hawaii (Clark, 2010).

Areas to which mantas travel when they leave coral reefs or coastal areas are still enigmatic. The nocturnal movements of reef mantas might be driven by the presence of demersal zooplankton that emerge from the reef benthos at night (Braun et al., 2014). In eastern Australia, a recent study suggested that demersal zooplankton, which is highly abundant in shallow coastal areas, are an important dietary source for reef mantas, as they do not appear to feed predominantly on near-surface zooplankton. They are generally larger than pelagic zooplankton, contributing to greater biomass (Couturier et al., 2013). Demersal zooplankton, which either inhabit bottom substrates or live near the bottom, emerge into the water column as they are vertically migrating at night, though they often remain close to the substrate instead of swimming far into the water column (Alldredge \& King, 1977, 1980).

Another possible argument is that the mantas travel offshore during the night to forage on zooplankton in the deep scattering layer (DSL) that migrate up to shallower waters during the night (Anderson et al., 2011; Clark, 2010). In general, zooplankton perform diel migration, in which they aggregate in deeper water during the day but then move into shallow water at night (Iwasa, 1982; Lampert, 1989; van Haren \& Compton, 2013). Reef mantas may be targeting these zooplankton at night when they are shallow and relatively more accessible, though nonetheless offshore from the reefs they frequent during the day.

\section{Passive acoustic telemetry}

The deployment of a passive acoustic array in northern Raja Ampat has enabled monitoring of the movements of reef mantas there over a multi-year period, providing important insights into the daily and seasonal movement patterns. In this study, passive acoustic monitoring revealed that the tagged individuals exhibited not only seasonal migration patterns, but also site preference, and that preference varied between individuals. The frequent re-detection event periods recorded by individuals at the same site/s throughout the study suggests this species exhibit strong site fidelity (Dewar et al., 2008; Anderson et al., 2011; Couturier et al., 2011; Braun et al., 2015).
The relatively narrow detection range of the receivers leaves blind zones in anything but the most densely-packed receiver array, imposing limits on the ability to locate mantas and detect their movements. Satellite tagging may allow for the tracking of manta movements within these acoustic blind zones. Using a combination of passive acoustic telemetry and satellite tracking can be an effective way of providing adequate information for thoroughly understanding the behaviour and movements of highly migratory species (Meyer et al., 2010).

\section{Implications for manta ray management}

The design and implementation of management programmes for marine migratory species is challenging and necessitates new approaches (Runge et al., 2014), and is optimally based upon a comprehensive understanding of their movement ecology (Grüss et al., 2011). The knowledge gained from this study can be used to inform Marine Protected Area (MPA) managers and local government in designing a management plan for Raja Ampat's reef manta rays. Despite the fact that both the Indonesian national and Raja Ampat local governments have officially legislated the protection of reef manta rays, management strategies for this highly mobile species should consider a number of factors to effectively achieve conservation goals. These factors include location of key aggregation sites, when these sites are used by mantas, environmental correlates affecting the presence of manta rays at these sites, and potential threats (including tourism) affecting manta rays and their associated aggregation sites (Lascelles et al., 2014). Designing and implementing site-specific protections for important manta aggregation sites within the existing MPAs and developing new manta-focused MPAs are two immediate steps that can be taken to better protect this species in Raja Ampat. The majority of the aggregation sites examined in this study are within existing permanent MPAs in Raja Ampat. Indeed, they were purposefully included during the gazette and zonation process (Agostini et al., 2012), and as such benefit from dedicated patrols and specific zonation regulations. Nonetheless, the rapid growth of manta-focused tourism in these MPAs over the past decade has led to a situation where additional controls and tourism management at popular manta aggregation sites is now urgently needed to prevent disturbance by divers and snorkelers to manta behaviour and especially to prevent boat and propeller strikes to surface-feeding mantas. Fortunately, in part due to the information provided by this study, the Raja Ampat government and local tourism opera- 
tors and NGO stakeholders have recently moved to implement strict visitor management in the vicinity of Manta Ridge and especially the nearby cleaning station known as Manta Sandy (Kasmidi \& Gunadharma, 2017). Based upon the already positive results of this management intervention, similar plans are now being discussed for other aggregation sites including Wai and Yefnabi Kecil.

Several of the aggregation sites examined in this study are not currently in MPAs, with the most important example being Eagle Rock. As part of the Raja Ampat government's commitment to developing a comprehensive manta ray management plan, discussions are now ongoing to consider the siting of a new manta-focused MPA to protect the Eagle Rock aggregation site and surrounding reefs. In addition to such spatial protection approaches, temporal approaches to management (Allen \& Singh, 2016) such as the implementation of seasonal closures of certain manta aggregation sites, as well as limitation of manta tourism visitation hours, are also being considered by the Raja Ampat government. An example of seasonal closures might include closures during period of important activities, such as reproductive activity. It is increasingly clear that reef manta aggregations at cleaning stations are driven by social behaviour, such as courtship activity. This often peaks seasonally (Stevens, 2016).

\section{Conclusions}

The use of passive acoustic telemetry has helped reveal the preferred aggregation sites and movement patterns of reef mantas in northern Raja Ampat. There were at least four main preferred aggregation sites of reef mantas in this region, namely Eagle Rock, Yefnabi Kecil, Manta Ridge, and Wai. The tagged mantas demonstrated high site fidelity to a number of sites that have been identified as manta aggregation sites for feeding and cleaning. Concurrently with their site fidelity, the mantas also exhibited consistent seasonal movement patterns along a roughly $100 \mathrm{~km}$ corridor from the Dampier Strait to the west of Waigeo, which are likely related to the seasonal monsoon and its effect on zooplankton abundance. Furthermore, the spatial movement of reef manta rays also suggests that there appears to be several population segregations in Raja Ampat region, including those in the northern and southern region.

Future studies in Raja Ampat incorporating environmental parameters should allow us to better identify significant drivers affecting the movement ecology of this charismatic filter feeder. Additionally, the integration of satellite tracking should further help to elucidate the fine-scale movements of reef mantas in
Raja Ampat. The use of photo identification would be very beneficial to discern between resident and transient individuals, considering that there are probably many other preferred and important aggregation sites in the region that have not been discovered yet. Finally, population genetic studies are planned to investigate the genetic variability of Raja Ampat reef manta rays and determine connectivity across the archipelago.

\section{Acknowledgements}

Conflict of Interest: The authors declare that they have no conflict of interest. Financial support for the fieldwork was generously provided by the Allchin Family's Sunbridge Foundation, the Wolcott Henry Foundation, Alex and Sybilla Balkanski, the Paine Family Trust, and an Australia Awards Scholarship to the first author. We would like to thank all of the staff at Conservation International Indonesia for their excellent support during fieldwork. We moreover thank the captain and crews of the MV Putiraja and the MV Inbekwan and the Yaswal for their tireless support of this fieldwork. Finally, we thank the traditional communities and the regency government of Raja Ampat, and especially the UPTD-BLUD Raja Ampat MPA Management Authority, for hosting and supporting this work. Special thanks to reviewers for their assistance and review during the process of this paper's publication.

\section{References}

Agostini V.N., Grantham H.S., Wilson J., Mangubhai S., Rotinsulu C., Hidayat N., Muljadi A., Muhajir M.M., Darmawan A., Rumetna L., Erdmann M.V., Possingham H.P. 2012. Achieving fisheries and conservation objectives within marine protected areas: zoning the Raja Ampat network. The Nature Conservancy, Indo-Pacific Division, Denpasar. Report No. 2/12. 71 p.

Alldredge A., King J. 1977. Distribution, abundance, and substrate preferences of demersal reef zooplankton at Lizard Island Lagoon, Great Barrier Reef. Marine Biology 41(4): 317-333. DOI: 10.1007/BF00389098

Alldredge A.L., King J.M. 1980. Effects of moonlight on the vertical migration patterns of demersal zooplankton. Journal of Experimental Marine Biology and Ecology 44(2): 133-156. DOI: 10.1016/0022-0981(80)90150-1

Allen A.M., Singh N.J. 2016. Linking Movement Ecology with Wildlife Management and Conservation. Frontiers in Ecology and Evolution 3: 155. DOI: 10.3389/fevo.2015.00155

Anderson R.C., Adam M.S., Goes J.I. 2011. From monsoons to mantas: seasonal distribution of Manta alfredi in the Maldives. Fisheries Oceanography 20(2): 104-113. DOI: $10.1111 /$ j.1365-2419.2011.00571.x

Braun C.D., Skomal G.B., Thorrold S.R., Berumen M.L. 2014. Diving behavior of the reef manta ray links coral reefs with adjacent deep pelagic habitats. PLOS ONE 9(2): e88170. DOI: 10.1371/journal.pone.0088170

Braun C.D., Skomal G.B., Thorrold S.R., Berumen M.L. 2015. Movements of the reef manta ray (Manta alfredi) in the Red 
Sea using satellite and acoustic telemetry. Marine Biology 162(12): 2351-2362. DOI: 10.1007/s00227-015-2760-3

Campbell H.A., Watts M.E., Dwyer R.G., Franklin C.E. 2012. V-Track: software for analysing and visualising animal movement from acoustic telemetry detections. Marine and Freshwater Research 63(9): 815-820. DOI: $10.1071 / \mathrm{MF} 12194$

Castro A., Stewart B., Wilson S., Hueter R., Meekan M., Motta P., Bowen B., Karl S. 2007. Population genetic structure of Earth's largest fish, the whale shark (Rhincodon typus). Molecular Ecology 16(24): 5183-5192. DOI: $10.1111 / \mathrm{j} .1365-294 X .2007 .03597 . \mathrm{x}$

Clark T.B. 2010. Abundance, home range, and movement patterns of manta rays (Manta alfredi, M. birostris) in Hawaii. PhD Thesis. Honolulu: University of Hawaii at Manoa. 149 p.

Couturier L.I., Dudgeon C., Pollock K.H., Jaine F., Bennett M., Townsend K., Weeks S., Richardson A. 2014. Population Dynamics of the reef manta ray Manta alfredi in eastern Australia. Coral Reefs 33(2): 329-342. DOI: 10.1007/s00338-014-1126-5

Couturier L.I., Jaine F.R., Townsend K.A., Weeks S.J., Richardson A.J., Bennett M.B. 2011. Distribution, site affinity and regional movements of the manta ray, Manta alfredi (Krefft, 1868), along the east coast of Australia. Marine and Freshwater Research 62(6): 628-637. DOI: $10.1071 / \mathrm{MF} 10148$

Couturier L.I., Marshall A., Jaine F., Kashiwagi T., Pierce S., Townsend K., Weeks S., Bennett M., Richardson A. 2012. Biology, ecology and conservation of the Mobulidae. Journal of Fish Biology 80(5): 1075-1119. DOI: 10.1111/j.1095-8649.2012.03264.x

Couturier L.I., Rohner C.A., Richardson A.J., Marshall A.D., Jaine F.R., Bennett M.B., Townsend K.A., Weeks S.J., Nichols P.D. 2013. Stable isotope and signature fatty acid analyses suggest reef manta rays feed on demersal zooplankton. PLOS ONE 8(10): e77152. DOI: 10.1371/ journal.pone.0077152

Deakos M.H., Baker J.D., Bejder L. 2011. Characteristics of a manta ray Manta alfredi population off Maui, Hawaii, and implications for management. Marine Ecology Progress Series 429: 245-260.

Delaney D.G., Johnson R., Bester M.N., Gennari E. 2012. Accuracy of using visual identification of white sharks to estimate residency patterns. PLoS ONE 7(4): e34753. DOI: 10.1371/journal.pone.0034753

Dewar H., Mous P., Domeier M., Muljadi A., Pet J., Whitty J. 2008. Movements and site fidelity of the giant manta ray, Manta birostris, in the Komodo Marine Park, Indonesia. Marine Biology 155(2): 121-133. DOI: 10.1007/s00227-008-0988-x

Donaldson M.R., Hinch S.G., Suski C.D., Fisk A.T., Heupel M.R., Cooke S.J. 2014. Making connections in aquatic ecosystems with acoustic telemetry monitoring. Frontiers in Ecology and the Environment 12(10): 565-573. DOI: $10.1890 / 130283$
Erdmann M.V. 2014. Indonesia Gives Mantas A New 'Ray of Hope'. In: Conservation International. Available from: https://blog.conservation.org/2014/02/indonesia-givesmantas-a-new-ray-of-hope/

Fox M. 2013. Raja Ampat Launches Indonesia's First Shark Sanctuary. In: Conservation International. Available from: https://blog.conservation.org/2013/02/raja-ampat-launches-indonesias-first-shark-sanctuary/

Germanov E.S., Marshall A.D. 2014. Running the gauntlet: regional movement patterns of Manta alfredi through a complex of parks and fisheries. PLoS ONE 9(10): e110071. DOI: 10.1371/journal.pone.0110071

Graham R.T., Witt M.J., Castellanos D.W., Remolina F., Maxwell S., Godley B.J., Hawkes L.A. 2012. Satellite tracking of manta rays highlights challenges to their conservation. PLoS ONE 7(5): e36834. DOI: 10.1371/ journal.pone.0036834

Grüss A., Kaplan D.M., Guénette S., Roberts C.M., Botsford L.W. 2011. Consequences of adult and juvenile movement for marine protected areas. Biological Conservation 144(2): 692-702. DOI: 10.1016/j.biocon.2010.12.015

Guisan A., Edwards T.C., Hastie T. 2002. Generalized linear and generalized additive models in studies of species distributions: setting the scene. Ecological Modelling 157(2): 89-100. DOI: 10.1016/S0304-3800(02)00204-1

Hastie G.D., Swift R.J., Slesser G., Thompson P.M., Turrell W.R. 2005. Environmental models for predicting oceanic dolphin habitat in the Northeast Atlantic. ICES Journal of Marine Science: Journal du Conseil 62(4): 760-770. DOI: 10.1016/j.icesjms.2005.02.004

Heinrichs S. 2013. Manta Ray Research Boosts Smart Policies and Ecotourism in Indonesia. In: Conservation International. Available from: https://blog.conservation. org/2013/12/manta-ray-research-boosts-smart-policiesand-ecotourism-in-indonesia/

Heupel M., Semmens J., Hobday A. 2006. Automated acoustic tracking of aquatic animals: scales, design and deployment of listening station arrays. Marine and Freshwater Research 57(1): 1-13. DOI: 10.1071/MF05091

Heupel M.R., Simpfendorfer C.A., Fitzpatrick R. 2010. Large-scale movement and reef fidelity of grey reef sharks. PLoS ONE 5(3): e9650. DOI: 10.1371/journal. pone.0009650

Heupel M.R., Webber D.M. 2012. Trends in acoustic tracking: where are the fish going and how will we follow them? In: J.R. McKenzie, B. Parsons, A.C. Seitz, R.K. Kopf, M.G. Mesa, Q. Phelps (Eds.): Advances in Fish Tagging and Marking Technology. American Fisheries Society, Symposium 50. Bethesda, MD. P. 219-231.

Iwasa Y. 1982. Vertical migration of zooplankton: a game between predator and prey. American Naturalist 120(2): 171-180. DOI: $10.1086 / 283980$

Jaine F., Rohner C., Weeks S., Couturier L., Bennett M., Townsend K., Richardson A. 2014. Movements and habitat use of reef manta rays off eastern Australia: 
Offshore excursions, deep diving and eddy affinity revealed by satellite telemetry. Marine Ecology Progress Series 510: 73-86. DOI: 10.3354/meps10910

Jaine F.R., Couturier L.I., Weeks S.J., Townsend K.A., Bennett M.B., Fiora K., Richardson A.J. 2012. When giants turn up: sighting trends, environmental influences and habitat use of the manta ray Manta alfredi at a coral reef. PLoS ONE 7(10): e46170. DOI: 10.1371/journal. pone. 0046170

Kashiwagi T. 2014. Conservation biology and genetics of the largest living rays: manta rays. $\mathrm{PhD}$ Thesis. Brisbane: University of Queensland. $169 \mathrm{p}$.

Kashiwagi T., Marshall A.D., Bennett M.B., Ovenden J.R. 2012. The genetic signature of recent speciation in manta rays (Manta alfredi and $M$. birostris). Molecular Phylogenetics and Evolution 64(1): 212-218. DOI: 10.1016/j.ympev.2012.03.020

Kasmidi M., Gunadharma A. 2017. Diving in Manta Sandy? Here's what you need to know! In: Bird's Head Seascape. Available from: http://birdsheadseascape.com/ diving/diving-manta-sandy-heres-need-know-meidiarti-kasmidi-nikka-amandra-gunadharma/

Kessel S., Cooke S., Heupel M., Hussey N., Simpfendorfer C., Vagle S., Fisk A. 2014. A review of detection range testing in aquatic passive acoustic telemetry studies. Reviews in Fish Biology and Fisheries 24(1): 199-218. DOI: $10.1007 / \mathrm{s} 11160-013-9328-4$

Kitchen-Wheeler A.-M., Ari C., Edwards A.J. 2012. Population estimates of Alfred mantas (Manta alfredi) in central Maldives atolls: North Male, Ari and Baa. Environmental Biology of Fishes 93(4): 557-575. DOI: 10.1007/s10641-011-9950-8

Lampert W. 1989. The adaptive significance of diel vertical migration of zooplankton. Functional Ecology 3(1): 21-27. DOI: $10.2307 / 2389671$

Lascelles B., Notarbartolo Di Sciara G., Agardy T., Cuttelod A., Eckert S., Glowka L., Hoyt E., Llewellyn F., Louzao M., Ridoux V., Tetley M.J. 2014. Migratory marine species: their status, threats and conservation management needs. Aquatic Conservation: Marine and Freshwater Ecosystems 24(S2): 111-127. DOI: 10.1002/aqc.2512

Lea J.S.E. 2017. Migratory behaviour and spatial dynamics of large sharks and their conservation implications. PhD Thesis. Plymouth: University of Plymouth.

Mangubhai S., Erdmann M.V., Wilson J.R., Huffard C.L., Ballamu F., Hidayat N.I., Hitipeuw C., Lazuardi M.E., Pada D., Purba G., Rotinsulu C., Rumetna L., Sumolang K., Wen W. 2012. Papuan Bird's Head Seascape: Emerging threats and challenges in the global center of marine biodiversity. Marine Pollution Bulletin 64(11): 2279-2295. DOI: 10.1016/j.marpolbul.2012.07.024

Marshall A, Dudgeon C, Bennett M. 2011. Size and structure of a photographically identified population of manta rays Manta alfredi in southern Mozambique. Marine Biology 158(5): 1111-1124. DOI: $10.1007 /$ s00227-011-1634-6
Marshall A.D., Bennett M.B. 2010. Reproductive ecology of the reef manta ray Manta alfredi in southern Mozambique. Journal of Fish Biology 77(1): 169-190. DOI: 10.1111/j.1095-8649.2010.02669.x

Marshall A.D., Compagno L.J., Bennett M.B. 2009. Redescription of the genus Manta with resurrection of Manta alfredi (Krefft, 1868) (Chondrichthyes; Myliobatoidei; Mobulidae). Zootaxa 2301: 1-28. DOI: 10.5281/zenodo. 191734

Meyer C.G., Papastamatiou Y.P., Holland K.N. 2010. A multiple instrument approach to quantifying the movement patterns and habitat use of tiger (Galeocerdo cuvier) and Galapagos sharks (Carcharhinus galapagensis) at French Frigate Shoals, Hawaii. Marine Biology 157(8): 1857-1868. DOI: 10.1007/s00227-010-1457-x

Ministry of Marine Affairs and Fisheries. 2014. Keputusan Menteri Kelautan dan Perikanan Republik Indonesia №4/Kepmen-KP/2014 tentang Penetapan Status Perlindungan Penuh Ikan Pari Manta. Jakarta, Indonesia: Ministry of Marine Affairs and Fisheries. 4 p.

Mourier J. 2012. Manta rays in the Marquesas Islands: first records of Manta birostris in French Polynesia and most easterly location of Manta alfredi in the Pacific Ocean, with notes on their distribution. Journal of Fish Biology 81(6): 2053-2058. DOI: 10.1111/j.10958649.2012.03449.x

O’Malley M.P., Lee-Brooks K., Medd H.B. 2013. The global economic impact of manta ray watching tourism. PLoS ONE 8(5): e65051. DOI: 10.1371/journal.pone.0065051

Runge C.A., Martin T.G., Possingham H.P., Willis S.G., Fuller R.A. 2014. Conserving mobile species. Frontiers in Ecology and the Environment 12(7): 395-402. DOI: $10.1890 / 130237$

Rykaczewski R.R., Checkley D.M. 2008. Influence of ocean winds on the pelagic ecosystem in upwelling regions. Proceedings of the National Academy of Sciences 105(6): 1965-1970. DOI: 10.1073/pnas.0711777105

Stevens G.M.W. 2016. Conservation and Population Ecology of manta rays in the Maldives. PhD Thesis. York: University of York.

Stewart J.D., Beale C.S., Fernando D., Sianipar A.B., Burton R.S., Semmens B.X., Aburto-Oropeza O. 2016. Spatial ecology and conservation of Manta birostris in the Indo-Pacific. Biological Conservation 200: 178-183. DOI: 10.1016/j.biocon.2016.05.016

Susanto R.D., Moore T.S., Marra J. 2006. Ocean color variability in the Indonesian Seas during the SeaWiFS era. Geochemistry, Geophysics, Geosystems 7(5): Q05021. DOI: 10.1029/2005GC001009

van Haren H., Compton T.J. 2013. Diel vertical migration in deep sea plankton is finely tuned to latitudinal and seasonal day length. PLOS ONE 8(5): e64435. DOI: 10.1371/journal.pone.0064435

Ware D.M., Thomson R.E. 2005. Bottom-up ecosystem trophic dynamics determine fish production in the North- 
east Pacific. Science 308(5726): 1280-1284. DOI: 10.1126/science. 1109049

Weeks S.J., Magno-Canto M.M., Jaine F.R.A., Brodie J., Richardson A.J. 2015. Unique sequence of events triggers manta ray feeding frenzy in the Southern Great Barrier Reef, Australia. Remote Sensing 7(3): 3138 3152. DOI: $10.3390 /$ rs 70303138

Whitney N.M., Pyle R.L., Holland K.N., Barcz J.T. 2012. Movements, reproductive seasonality, and fisheries interactions in the whitetip reef shark (Triaenodon obe- sus) from community-contributed photographs. Environmental Biology of Fishes 93(1): 121-136. DOI: 10.1007/s10641-011-9897-9

Wood S., Wood M.S. 2007. The mgev package. Available from: www r-project org

Wood S.N. 2011. Fast stable restricted maximum likelihood and marginal likelihood estimation of semiparametric generalized linear models. Journal of the Royal Statistical Society: Series B (Statistical Methodology) 73(1): 3-36. DOI: 10.1111/j.1467-9868.2010.00749.x

\title{
ОПРЕДЕЛЕНИЕ ПРИУРОЧЕННОСТИ И ХАРАКТЕРА ПЕРЕМЕЩЕНИЙ MOBULA ALFREDI (МOВULIDAE) С ПОМОЩЬЮ МЕТОДА ПАССИВНОЙ АКУСТИЧЕСКОЙ ТЕЛЕМЕТРИИ В СЕВЕРНОЙ ЧАСТИ РАДЖА-АМПАТ, ИНДОНЕЗИЯ
}

\author{
Е. Сетиаван ${ }^{1,2,3, *}$, А. Б. Сианипар ${ }^{4}$, М. В. Эрдманн ${ }^{5}$, Э. М. Фишер ${ }^{1}$, \\ Дж. А. Хадди ${ }^{1}$ К. С. Биэл ${ }^{6}$, С. А. Льюис ${ }^{2,3,6}$, Р. Мамбрасар ${ }^{4}$ \\ ${ }^{1}$ Институт морских и антарктических исследований Университета Тасмании, Австралия \\ ${ }^{2}$ Сохранение морских заказников, Великобритания \\ ${ }^{3}$ Сохранение манть - Манта проект Индонезии, Индонезия \\ ${ }^{4}$ Общество сохранения природы Индонезии -морская программа, Индонезия \\ ${ }_{5}^{5}$ Международное общество сохранения природы - Тихоокеанские морские программы, Новая Зеландия \\ ${ }^{6}$ Мисоол Манта проект, Индонезия \\ *e-mail:edysetyawan@gmail.com
}

Несмотря на крайнюю ценность для местной индустрии морского туризма, существует недостаток опубликованной информации об экологии и демографической динамике рифовой манты (Mobula alfredi) в Раджа Ампат, Западное Папуа, Индонезия. Необходимо неотложное познание экологии перемещений в особенности этой большой и рассредоточенной популяции для улучшения управления быстро развивающегося туризма, связанного с мантой. Здесь мы сообщаем о первых результатах исследований с помощью пассивной акустической телеметрии для предоставления местным менеджерам первых подробных сведений об использовании особенностей местообитаний и перемещений рифовых мант в северной части Раджа Ампат. В общей сложности 39 рифовых мант были отмечены акустическими регистраторами Vemco V16 в течение 15 месяцев (с 27 ноября 2013 г. по 22 февраля 2015 г.). Для мониторинга их передвижений акустические приемники VR2W были установлены на восьми участках, соответствующих известным местам чистки и кормления мант. Причем приемники загружались каждые шесть месяцев в течение двухлетнего периода первоначального мониторинга. Продолжительность времени от установки приемников до последней даты обнаружения животных на участках составляла от 1 до 682 дней (среднее значение $\pm \mathrm{SE}=237 \pm 27)$. Общее количество дней регистрации отдельных особей манты на участках с помощью приемников изменялось от 1 до 188 дней (среднее $\pm \mathrm{SE}=42 \pm 7$ ). Манта Ридж явился самым посещаемым участком с 565 днями регистрации. Помеченные манты демонстрировали строгую приуроченность к участкам в наблюдаемых местах скопления животных, но также они показали сезонные перемещения в коридоре длиной около 150 км между участками в проливе Дампир и северо-западнее острова Вайгео. Данные, проанализированные из соседнего массива из шести VR2W-приемников на юге Раджа Ампат (примерно в 180 км к югу от района исследования), подтвердили, что в этом массиве не было обнаружено ни одного из помеченных мант. Это еще больше свидетельствует о строгой приуроченности мант к участкам и ограниченные перемещения в пределах архипелага Раджа Ампат. Более 96\% регистраций совершено в дневное время. Число регистраций достигло пика около полудня на участках Йефнаби Кецил и Игл Рок и немного ранее на участке Манта Ридж. Эти результаты были переданы Управлению по охране морских особо охраняемых природных территорий Раджа-Ампат. И в настоящее время они используются при разработке плана менеджмента этих уязвимых и экономически важных видов для обеспечения долгосрочного благосостояния популяции рифовых мант Раджа Ампата и устойчивости связанного с мантой туризма в этом регионе.

Ключевые слова: управление, морские особо охраняемые природные территории, рифовая манта, сезонное перемещение, мечение, Западное Папуа 